\title{
Effect of Equity Finance on Financial Performance of Small and Medium Enterprises in Kenya
}

\author{
Mutie Juliet mwende \\ Prof. Willy Muturi \\ Dr. Agnes Njeru \\ School of Business JKUAT \\ Nairobi CBD \\ Kenya
}

\begin{abstract}
All business enterprises are mostly acknowledged as an important contributor of poverty eradication and increasing economic growth all over the world. Despite the role of SMEs in building economic development in Kenya, they are facing several challenges among them being choosing the best source of finance for their successful performance. Purposely this study was to determine the effect of sources of finance on financial performance of small and medium sized enterprises in Kenya. The specific objectives were; to determine the effect of loans on financial performance of SMEs in Kenya, to identify the effect of trade credit on financial performance of SMEs in Kenya, to find out the effect of equity financing on financial performance of SMEs in Kenya, to establish the effect of informal finances on financial performance of SMEs in Kenya, to determine the moderating effect of firm size on the effect of sources of finance on financial performance of SMEs in Kenya. The target population of the study was 291,449 licensed SMEs in the selected counties by operational wholesale and retail trade. Simple random techniques were used to collect the sample for the study. 384 respondents made up the sample and were selected from the six selected counties which comprised of Nairobi County, Mombasa County, Machakos County, Makueni County, Kajiado County and Kitui County. Secondary and primary data were useful to provide information in this study which was either quantitative or qualitative. Through a structured questionnaire data was collected and these questionnaires were dropped and later picked as the method gave respondents enough time to think about their responses carefully without interference. Determining of the reliability of the questionnaire was done by using Cronbach Alpha. The study made use of Statistical Package for Social Sciences (SPSS) version 22.0 to aid in coding, entry and analysis of quantitative data. By using regression and correlation analysis data was analyzed and this helped to test the connection between the independent and dependent variables. Data was analyzed by use of descriptive and inferential statistics and then presented through figures, tables, percentages, arithmetic means, standard deviations and tabulation to show differences in frequencies. The findings revealed that there is a statistical significant relationship between the independent variables which comprised of Loans, Trade credit, Equity financing and Informal financing and the dependent variable Financial performance of the SMEs in Kenya. The study established that the trade credit had the strongest relationship with the financial Performance of SMEs in Kenya, then equity financing, loans and finally informal financing respectively. The study clearly concluded that there is no one source of finance that fully contribute to the financial performance of the SMEs in Kenya. The recommendation by this study was that, the SMEs in Kenya should use the four sources of finance together but should embrace more use of trade credit.
\end{abstract}

Keyterms; Equity financing, Financial performance, SMEs

\section{Introduction}

Promotion of SME sector in Kenya is very important for attaining the national goals and vision 2030 (Wambui, 2015). The SME sector is very important engine for job creation, innovation, poverty eradication hence main driver for economic growth (Katua, 2014; Emad, Suhail \& Jabbar, 2014). SMEs are important for rapid technological development and provision of job opportunities in any country (Njeru, 2013).

SMEs are very important and are the backbone of emerging economies and are a key source of income for most people in the country (Economic survey report, 2017). SME sector is very important in the European sector as it employ $70 \%$ of the workforce and produce 66\% of the exported products (Njeru, 2013). Mostly countries are showing more concern and involvement on the improvement and development of the SMEs because of the significance that they have on development in all dimensions (Kangala , 2016). The availability of monetary resources is a very critical component for the performance of the SMEs (Muriithi, 2014). Sourcing finance is one of the big problems hindering start up and growth of SMEs, in that the type of finance determines success of SMEs (Njeru , 2013). 
SMEs encounter many problems which make them perform poorly and reduce their growth. There is high probability of SMEs failing within the first two years after their start up (Kamunge, Njeru \& Tirimba, 2014). Despite the SMEs importance in Kenya, 2.2 million SMEs shutdown in the last five years including year 2016 (Kenya national bureau of statistics report, 2016). Finance is very important for the betterment and development of the SMEs sector which has received high appreciation as the core driver and the backbone of the national economy in every country due to its nature of stimulating job creation, innovations and poverty alleviation among other things (Kamau, 2011). Finance is very crucial to any business and is totally seen as the life- blood of any kind of business enterprise and no business unit can do well without enough monetary resources for investing (Akinyi, 2014). Finance is usually an important aspect that contributes to development of SMEs, whether at their initial stage or at their subsequent stages in life (Onyiego, Namusonge \&Waiganjo, 2017). Increasing the rate of economic development depends heavily upon having the finance required for investment (Rosana \& Muturi, 2014).

Finances have been seen to have high importance and are viewed as an essential element for any SMEs. Thus high degree of accessibility to finance is a key factor to SMEs growth and without it many SMEs languish and stagnate ( Kangala , 2016). According to Njeru (2013) choosing the better source of finance is the most significant factor that has high contribution to the growth of small firms. Financing is very much considered for the SMEs' growth since it enables the firms to market their goods and services, expand production capacity, and sustain sufficient operating cash flow (Grover\& Suominen, 2014). It is therefore absolutely imperative to raise finance in the most efficient and effective means to enjoy tax allowances, low cost of funds, liquidity and reduce overall risk of the business (Kenduiwo, 2014).

\section{SMEs Performance in Kenya}

SME sector has been identified and prioritized as a key growth driver for achievement of the development blue print (Economic survey report ,2017).SMEs have been recognized as a greater contributor to the Kenyan economy offering both employment and platform for innovative ideas. The SMEs offer about $75 \%$ of the general employment and contributing about $18 \%$ of the GDP in the Kenyan economy (Kangala, 2016). SMEs in Kenya serve as live blood to the poor; create employment opportunities, generate income and contribute to economic growth ( Mukoma \& Masini, 2015). According to Katua (2014) SMEs have been accepted as the core engine of economic growth and poverty eradication in the world.

SMEs form a larger percentage of the businesses that operate in Kenya as compared to their counterpart the large companies. According to Economic survey report (2016) there were 1.56 Million licensed SMEs and 5.85 Million unlicensed SMEs, where wholesale and retail trade accounted for $57.1 \%$ which was more than half of the licensed businesses in that year. Despite the fact that SMEs have become very key and important players in the Kenyan economy there still some challenging situations being faced by SMEs that limit their development and betterment. The problem of choosing the best source of finance is the major challenge. Mostly SMEs rely on borrowing from friends and relatives or self-financing (kamau, 2011). Banks are not providing enough support to SMEs for one reason or the other and this affect their faster growth (Chimaleniet al.,2015).

In Kenya there is relatively strong competition between banks, Micro finance institutions (MFIs) and deposit taking Micro Finance Banks, (MFBs) to support and finance SMEs in Kenya ( FSD Kenya \& Growth Cap, 2016). Access to appropriate finance is a major constraint among smaller businesses in Kenya. Despite this, SMEs form a significant part of the potential financial market for banks and other lending institutions in Kenya. According to Mwega (2014) SMEs in Kenya are provided with financial services by a range of institutions; banks, non-bank financial institutions, savings and credit cooperatives (SACCOs), microfinance institutions and alternative sources.

Most banks in Kenya require SMEs to provide collateral that includes land title deeds, motor vehicle log books, guarantees, listed shares, as well as cash in the form of deposits. Some financial institution accepts alternative forms of collateral, such as household goods, which is easily accessible to smaller or less formal SMEs (FSD Kenya \& Growth Cap, 2016). Personal income, Bank loans, Venture capital, Leasing, Sale of shares, Government loans and Microfinance loans are used to finance most SMEs in Kenya, but commercial banks find it difficult to provide funds to SMEs as they consider them as high risk clients ( Muriithi , 2014). The Kenyan government value the very high worthiness of the SME sector to her economic development and for this reason the government has initiated finance schemes such as youth and women fund and Uwezo fund with a view to finance SMEs (Njagi ,Kimani \& Kariuki, 2017). 


\section{Statement of the Problem}

Improved access to finance has high probability of benefiting SMEs of all sizes (Kangala, 2016). One of the main conclusions of modern economics is that finance is very important for improving SMEs performance, however the debate on which source of finance has high significance effect on the SMEs performance has been an issue in accounting and finance (Emadet al., 2014).

Kenyan SME sector is growing in importance; as SMEs are estimated to account for $20 \%$ of GDP and $80 \%$ of employment hence SMEs have the scope to catalyze further industrialization in Kenya (Phyllis, 2016).According to Mwangi (2015) in Kenya SMEs are big contributors for economic growth and good financial performance of these entities is always very important and it is critically attributed with their economic contribution in one level or the other.

The government of Kenya has specified a number of key sectors that will prove instrumental in reaching its goals and mostly a middle income economy by 2030. In this plan, the government has aimed to create robust diversified and competitive SMEs and yet SMEs are failing. According to Janet and Ngugi (2014) most SMEs do not celebrate their third anniversary.

Despite the SMEs importance in Kenya, 2.2 million SMEs have shutdown in the last five years including year 2016 (KNBS report, 2016). According to this report most of the closed businesses were mostly those in wholesale and retail trade as well as repair of motor vehicles and motor cycles sector which accounted for $73 \%$ of the total closure. Mostly these SMEs closed at the age of 3.8 years. $46.3 \%$ of SMEs closed without even the first year of operation ending (Economic survey report, 2017).

Though SMEs are involved in the economic development of the country, their financial performance remains an issue of concern as many of them continually fails to pick up; three out of five SMEs fail within a very short time after their start up (Githire\& Muturi, 2015). In Kenya and other emerging economies SMEs performance has highly declined over the years. Many of the SMEs have collapsed due to poor performance (Chimaleniet al., 2015). The rate of SMEs failure in Kenya is very high ( Raude, Wesonga \& Wawire, 2015).

SMEs in Kenya do not grow into large enterprises (Githire\& Muturi, 2015). This failure of SMEs in Kenya may lead to social crimes with high probability of insecurity, low liquidity in the economy and losses of jobs and this result to threatening economic development and Kenya realization of vision 2030 ( Janet \&Ngugi ,2014). Most studies associate this failure of SMEs on financing. An important question then arises on what sources of finance significantly contribute to the best performance of the SMEs in Kenya. Then this study aimed at determining the effect of sources of finance on financial performance of SMEs in Kenya.

\section{Literature Review}

\section{Theoretical Framework}

A theory is a set of concepts or constructs and the interrelations that are assumed to exist among those concepts. A theory provides the basis for establishing the hypotheses to be tested in the study (Mugenda \& Mugenda, 2003). A theory is a set of interrelated statements that provides an explanation for a class of events. The study was guided by the following theories;

\section{The trade-off theory}

The developers of this theory were Modigliani and Miller (1958). This theory describes the concept that a company makes a choice on how much debt and how much equity to use by weighing the costs and benefits and balancing them out. The important part of this theory is to explain the fact that business units are usually financed partly with debt and partly with equity. The theory shows that there are merits of debt which may include tax benefit but on the other hand there are costs of debt which may be costs of financial distress including bankruptcy costs of debt. The marginal benefit of any increases in debt mostly decreases as debt increases, while the marginal cost increases. According to Myers (1984), the firm target capital should consider the benefits and costs of debts.

The target is determined by balancing debt tax shields against costs of bankruptcy. This theory is important as it helps the finance managers to make viable decisions when financing the business to ensure that benefits of the debt are more than costs. The implication of this theory is that any firm has a specific maximum amount of debt. The empirical relevance of the trade off theory has been questioned. Myers (1984) suggested that if this theory was true, then firms in the real world ought to have much higher debt levels than we observe in reality. Large firms tend to have a greater diversification of activities that implies less likelihood of bankruptcy. According to trade off approach large firms tend to increase their level of debt so as to increase the debt tax shields. The usefulness of this theory to this study was testing the effect of debt financing on the financial performance of SMEs in Kenya. 


\section{Pecking Order Theory}

Donaldson in 1961 suggested Pecking order theory and it was modified by Stewart Myers and Nicolas Majluf (1984). According to this theory firms are financially constrained due to the information asymmetry between managers/ owners and investors and then firms adopt a hierarchy in selecting sources of finance. According to this theory firms have to rank their sources of finances (Njagiet al., 2017).

Depending on this theory firms have three main sources to fund the financial needs which are internal funds, debt and new equity. The theory claims that mostly firms prefer to use firstly internal finances such as excess liquid assets or retained earnings. If it is necessary to turn to external finance firms use debt with little or no risk, which usually corresponds to short term debt and in the last place, firms will select external equity (Njagiet al., 2017). Njeru (2013) puts it that finances contributed internally are preferred by SMEs since they are usually very cheap and easier to arrange for by giving a short notification. If internal financing is not sufficient to fund investment projects, external funding may be sourced and if they do, in order to minimize costs the managers have to choose debt before using equity. According to Njeru (2013) internal finances are preferred to firms because they are cheaper and easy to get at a short notice.

This theory observes that businesses follow a hierarchy of financing and prefer internal financing first; debt is preferred over equity as equity would mean bringing external ownership into the company. The POT may fail to hold for SMEs where information asymmetry is an important problem (Njagiet al., 2017).

POT is important as it signals to the public how the company is performing. This means if the company finances itself internally it means it is a strong company and if the company has external financing then this shows high level of confident that the company has high chance of satisfying its obligations (Wahome, 2017). The critique of Pecking order theory is that it does not explain the influence of taxes and financial distress. The theory assumes that there is no target capital structure. The firms choose capital according to the following preference order; internal finance, debt finance and then equity finance. This may not be the case for most SMEs as they may lack retained earnings. The theory was useful to this study by testing the effect of equity financing on financial performance of the SMEs in Kenya.

\section{Financing Life Cycle of the firm}

The financial growth lifecycle theory was developed by Berger and Udell (1998). According to the financial growth life cycle theory, as with individual products, entrepreneurial firms go through a life cycle. An entrepreneurial firm may be at the idea stage, the prototype stage, the rapid growth stage, or the maturity stage. A number of researchers have pointed out that different types of finances are appropriate for different stages of firm development (Njeru , 2013). It is normal that during the earliest stages of the company, funding typically comes from the entrepreneur's personal financial resources and savings or from family and friends. This is because, at this stage, the firm often lacks a viable product, customers, or stable revenues (Onyiegoet al., 2017). According to this theory financial needs and financing options vary as the business grows and becomes more experienced.

When the firm grows and begins to generate revenues, however, angels and venture capitalists may take an interest (Onyiegoet al., 2017). When the firm achieves profitability and some measure of stability, bank loans may become an option (Amidu, 2007). Further, when the company has achieved significant revenues and growth, it may be a candidate for sale or for an initial public offering. Thus, a potential source of capital varies according to the age of the business. During the rapid growth stage, the firm consumes cash faster than it brings it in. This necessitates identifying and securing external financing (Namusonge, 2010). This theory was of value to this study as it showed that the financing needs of SMEs are highly dependent on their stage of growth and it will help to determine the type of finance appropriate for each stage of development for the firm. Critique on this theory is that it may not be appropriate for most SMEs as during the first stage a new company begins with an idea and it may mostly depend on external financing as it entirely needs money to develop but lacks retained earnings. The young firms are mostly and frequently financed through debt, acquiring loans from banks and close business associates (Caroline \&Muturi, 2015).

\section{Agency theory}

Agency theory was developed by Jensen and Meckling (1976). The theory put into consideration the conflict of interest between principals and agents. The agent represents the principal in business transaction and there is high expectation to represent the best interests of the principal without regard for self-interest. The principal and agents often have different goals and different risk tolerances which can lead to misunderstandings and a failure to agree on investing decisions. Agency theory focuses on the costs which are created due to differences of level of interest between principals and agents. According to this theory capital structure are determined by agency costs. 
According to the agency theory the optimal structure of the capital, results from a compromise between various funding options (equity, debts and hybrid securities) that allow the reconciliation of conflicts of interests between the capital suppliers ( shareholders and creditors) and managers. The ideal source of capital is the one that assures the least of total agency cost (Wahome, Muturi\&Memba, 2015). In this case managers, who are responsible, may guide the firm towards achieving their personal satisfaction of their goals rather than maximizing benefits to the shareholders. The major conflict that shareholders face is to ensure that managers (Agents) do not invest the free cash flow in unprofitable projects.

In other words increasing the amount of debt when compared to equity would ensure that firms make sure that managers are running the firm more efficiently. This explains why even without tax benefits, debt is a popularly used. The critique of agency theory is that the theory assumes that individuals behaviour is opportunistic self-serving and motivated by satisfying personal goals (Wahomeet al., 2015).

\section{Equity Financing}

Equity financing its where business individuals invest their personal funds into their businesses (Githire\&Muturi, 2015). Njeru (2013) defined equity financing as the difference between assets and liabilities of the business. Funds from personal savings or even the sale of personal assets is the main source of equity financing. Due to moral hazard and problem with information asymmetry then SMEs at the startup stage tend to use personal savings. In later stages in order to grow and develop the SMEs tend to seek for alternative sources of finance (Abdulaziz\&Andrew , 2013).

Angel investors are usually described as wealthy individuals or friends of the business owners or group ofindividuals who financially support small businesses because they have high believe that the business will have high growth and returns (Njagiet al., 2017). Mostly the amount invested is not more than $\$ 500$, 000, the terms of investments are favorable and the investor is not in one way or the other in the management of the business.

Venture capitalist financing involves professional investors who provide financial support to highly chosen businesses. Venture capitalist are risk averters and are very sensitive and choosy about investing only in businesses that are well managed and have high level of competitive advantage in their particular industry. Venture capitalists are normally very active in terms of managing the companies they invest in and they have high interest in maximizing the return on their investment. Venture capitalists mostly invest in a private business with the goal of eventually transforming it into a public company by offering shares on a security exchange (Memba , 2011).

According to Njagiet al., (2017) equity financing may include retained profits, own savings, contribution from friends, contribution from partners, deferred income and cash flow of the business. Equity financing ensures that SMEs have full control and the equity holders have to ensure that resources are allocated efficiently hence increasing financial performance (Githire\& Muturi, 2015). According to Njagiet al., (2017) SMEs that use Equity financing are seen to have a positive relation with the performance more so equity financing is said to have less risk since no fixed monthly loan repayments to make. This positive performance is mostly associated with the direct control that equity holders have in their businesses and also having in mind that the equity holders have the last claim to dividends they always have to ensure that the business resources are efficiently allocated (Githire\& Muturi, 2015).

Many SMEs are established as family businesses which may not pursue growth strategies (Githire\& Muturi, 2015). Moreover if SMEs have unconstrained choice between external debt and internal finances they will choose not to use debt financing because of the desire to retain control and independence of the business ( Njagiet al., 2017). According to Kepha and Muturi (2013) SMEs are financed by the owners and their relatives. They do not like access to external finance since this implies reduction in freedom in managing the firm hence SMEs use equity financing in order to retain control and independence. Equity financiers do not expect any immediate return from their money. Equity financing is not mandatory to be paid back like a loan. The businesses that use equity financing bear all the losses of the business in situation of a failure ( Njagiet al., 2017).

\section{Research Methodology}

\section{Research Design}

Kombo and Tromp (2006) explain research design as the glue that puts all the components in a research project together. The study made use of descriptive research design. Descriptive design is a method of collecting information by distributing a structured questionnaire to a sample of individuals or interviewing the individuals. This research design is appropriate for answering questions on the current state of affairs (Stangor, 2011). A descriptive research design attempts to describe things like attitudes, values, possible behaviour and characteristics and it also allows for collection of large data which enables the researcher to generalize the findings to the large population (Mugenda \& Mugenda, 2003). 


\section{Research Philosophy}

Research philosophy is a belief about how data about a phenomenon should be gathered, analyzed and used (Jackson, 2013). The fundamental question in any field of study concerns what constitutes acceptable knowledge in that field. Ihuah and Eaton (2013) noted research philosophies to include: positivism, epistemology and Constructivist among others. The main philosophy that guides social scientist researchers is positivism.

Epistemology poses questions on what is the relationship between the knower and what is known (Jackson, 2013). Constructivist philosophy sees the world as constructed, interpreted and experienced by people in their interactions with each other and with wider social systems. It beliefs that the truth and meaning do not exist in some external world but are created by the subjects interactions with the world meaning that it is constructed but not discovered. The purpose of inquiry is to understand a particular phenomenon not to generalize to a population (Antwi\&Hamza, 2015). Positivism is a philosophy of science that seeks facts of social phenomena with little regard for the subjective status of an individual (Ihuah\& Eaton, 2013). Positivism says that reality exist external to the researcher and must be investigated through the rigorous process of scientific inquiry. It beliefs that the world is independent of our knowledge of it, "it exist out there".

The study adopted the positivist philosophy which advocates for an objective interpretation of reality using hard data from surveys that are structured, formal, and have a specific and detailed plan (Antwi\&Hamza, 2015). The data collection focuses on gathering hard data in the form that enable evidence to be presented in quantitative form. Researchers who work from this perspective explains in quantitative terms how variables interact, shape events and cause outcomes (Ihuah\& Eaton, 2013). In positivism philosophy the research and researcher are independent of one another and this research can be measured using a questionnaire (Ihuah\& Eaton, 2013).

\section{Study population}

Population refers to the whole group of individuals, events or objects taken from general population having similar observable features (Kombo\& Tromp, 2006). The target population was drawn from all the 291,449 licensed SMEs in Nairobi County, Mombasa County, Machakos County, Makueni County, Kajiado County and Kitui County (KNBSCounty statistical abstract, 2017). The SMEs in the six counties were selected because these counties were among the best in terms of revenue collection (Kenya Commission on revenue allocation report 2017).

\section{Sampling Frame}

A sampling frame is the list of all the items where a representative sample is drawn for the purpose of research (Mugenda and Mugenda, 2003).The sampling frame constituted all the 207,947 licensed retail and wholesale SMEs in Nairobi County, Mombasa County, Narok County, Nakuru County, Kajiado County and UasinGishu County (KNBSCounty statistical abstract, 2017).

\section{Sample size}

Mugendaand Mugenda (2003) sample is the subgroup of individuals in the population from which information is collected. It is a smaller group obtained from the accessible population to show what the whole is like. The sample of 384 respondents was used. This sample was enough for descriptive research.

\section{Sampling Technique}

Sampling is the process of selecting individuals for a study in such a way that the selected individuals represent the large group from which they were selected (Kombo\& Tromp, 2006). It is the process of taking a subset of subjects that is representative of the whole population ( Mugenda\& Mugenda ,2003). A sample from the target population was obtained through Stratified random sampling, where the population was divided into strata and the researcher used simple random sampling to obtain respondents from each of the small group. Stratified sampling design was used because the population is heterogeneous. Stratified sampling helped the researcher achieve desired representation from sub groups in the population.

\section{Data Collection Instruments}

Instruments involve designing, developing, pilot testing, validation and compilation of final instrument. The researcher made use of questionnaires for the collection of data from owners or managers of SMEs under study. Anonymity of the respondents was ensured and this increased the chances of getting honest replies. The questionnaires allow the researcher to collect variety of information cheaply (Mugenda\& Mugenda, 2003).

\section{Data Collection Procedure}


Data collection refers to gathering of information to prove some facts (Kombo\& Tromp, 2006). Before the start of data collection, an introduction letter authorizing data collection was obtained from the university and then used to process a research permit from NACOSTI.

The drop and later pick method was used in administration of the questionnaire as it gave respondents enough time to think about their responses carefully without interference. Drop and later pick method also helps to collect data from a large representative sample of SMEs (Chimaleniet al ., 2015).

\section{Pilot Test}

Pilot test is the process of testing the research tool of the level of reliability and validity (Mugenda\& Mugenda, 2003). Once the questionnaire was finalized it was tried out in the field. A sample which is similar in characteristics to the actual sample was used for the pilot study. Respondents used in the pilot study were not part of the actual study. The same procedure used in pre- testing the questionnaire used during the actual data collection. This helped the researcher to make meaningful observation.

Mugenda and Mugenda (2003), puts it that a successful pilot study use 1\% to $10 \%$ making consideration of the sample size, where with large sample the percentage is small. Pre testing of the research instruments using a sample of four respondents which was $1 \%$ of the sample of 384 respondents was done. Pretest was used for identification of any possible problems such as instrument clarity, proper wording and appropriateness of the language used in the data collection tools. It helped to reveal vague questions or show questions interpreted differently by respondents. Necessary adjustments were made in case of problems related to the instruments for data collection.

\section{Validity of the research instrument}

Validity is the level to which the results obtained from the analysis of data actually represent the phenomenon under study. Validity ensures that the research instruments measures what is supposed to measure ( Mugenda \& Mugenda, 2003).The researcher discussed the prepared questionnaire with the supervisor and used test re-test method to ensure that the items are well set, for the content validity. This entailed administering the questionnaire twice to three respondents from SME. The data obtained was correlated with the data obtained earlier using the same questionnaire. This ensured that the right data was collected and ambiguous questions avoided. The period between the two administering was one week. Shorter period ensures that the environment does not change.

\section{Reliability of the research instrument}

Reliability is a measure of the degree to which a research instrument yields the same results after repeated trials (Mugenda\& Mugenda, 2003). The reliability was tested using Cronbach's alpha method of internal consistency which was developed by Lee Cronbach in 1951. Coefficient alpha measures internal consistency and tells if the test designed is accurately measuring the variable of interest. The coefficient alpha shows if the characteristics within the test are consistent (Chimaleniet al., 2015). Coefficient alpha of more than 0.70 is always acceptable to measure reliability.

\section{Data Analysis and presentation}

Data analysis refers to examining what has been collected in a survey or experiment and making deductions and inferences (Kombo\& Tromp, 2006). Mugenda and Mugenda (2003) observed that raw data obtained from the field is hard to interpret unless it is cleaned, coded and analyzed. Descriptive and inferential statistics helped in data analysis. The descriptive statistics considered frequencies, percentages, means and standard deviations. Inferential statistics such as correlation technique and multiple regression analysis were used to the effect of predictor variables to dependent variable. The researcher made use of the SPSS software version 22.0 for data entry and analysis. The presentation of the results was shown through figures, tables and percentages.

\section{Model specification}

Since the study has more than one independent variables then it used multiple regression model. Multiple regression model attempts to determine whether a group of variables together predict a given dependent variable (Mugenda\& Mugenda , 2003). The multiple regression model measures the effects of two or more independent variables on a single dependent variable. The multiple regression model helps the researcher to ask the general question on which is the best predictor variable. This study then used multiple regression model. The model was represented as follows:-

$\mathrm{Y}=\beta_{0}+\beta_{1} \mathrm{X}_{1}+\beta_{2} \mathrm{X}_{2}+\beta_{3} \mathrm{X}_{3}+\beta_{4} \mathrm{X}_{4}+e \ldots \ldots \ldots \ldots \ldots \ldots \ldots \ldots$ (i)

Where:

Y- Is the dependent variable which is performance of the SME: Measured as the ratio of return on Assets.

$\beta 0$ - Is constant.

$\mathrm{X}_{1}$ - is loans: Measured as the amount obtained against a security.

$\mathrm{X}_{2-}$ is trade credit: measured as accounts payable. 
$\mathrm{X}_{3}$ - is equity financing: Measured as amount of owners financing.

$\mathrm{X}_{4}$-is informal finances: Measured as amount from informal associations.

$e$ - Is the error term

The researcher used the following multiple regression model to show the moderating effect on the relationship of the predictor variable and the dependent variable.

$\mathrm{Y}=\beta_{0}+\beta_{1} \mathrm{X}_{1}+\beta_{2} \mathrm{X}_{2}+\beta_{3} \mathrm{X}_{3}+\beta_{4} \mathrm{X}_{4}+\mathrm{ZX}_{1}+\mathrm{ZX}_{2}+\mathrm{ZX}_{3}+\mathrm{ZX}_{4}+e$

Where $\mathrm{Z}$ is the moderating variable: measured as size of the firm.

\section{Findings and Discussion}

\section{Introduction}

This chapter presented an in-depth analysis and results within the framework objectives, research questions and the hypothesis. This chapter further put into discussion the findings obtained from the field concerning this study. Descriptive and inferential statistics were used to analyze the data. Furthermore, inferential statistical analysis was carried out for testing hypothesis and predicting the connections of the dependent variables and independent variables. Data analysis was in line with specific objectives that were instigated, analyzed, interpreted and various implications were drawn from them. The data was presented in various tables and figures that the researcher used to draw conclusions and recommendations. Finally, the researcher tested the reliability, regression model and all hypotheses of the independent variables.

\section{Response Rate}

A total of three hundred and fourteen (314) responses were received, translating into $81.8 \%$ response rate. However, fourteen questionnaires were poorly done and so they had to be discarded from being used for analysis, hence the correct filled questionnaires used were three hundred (300) that led to a vivid and subjective analysis that translated to a higher outcome of $78.1 \%$. Njeru (2013) considered that $50 \%$ to $75 \%$ is sufficient for data analysis. Based on this assumption, the response rate of $81.8 \%$ in this study was therefore very good and was considered useful to make conclusions for the study.

\section{Response Rate}

\begin{tabular}{lcc}
\hline Responses & Frequency & Percentage \\
\hline Respondent & 314 & 81.8 \\
Non- Respondent & 70 & 18.2 \\
Total & $\mathbf{3 8 4}$ & $\mathbf{1 0 0}$ \\
\hline
\end{tabular}

Table 4.1 shows high response rate. This was associated with the procedures of data collection, where the researcher pre-notified the potential participants of the intended survey, utilized a self-administered questionnaire where the respondents completed and immediately after, they were picked. Follow up calls were also made to clarify queries in the questionnaires. These findings were in line with Njeru (2013) where the study observed that use of selfadministered questionnaires give respondents enough time to provide well thought responses and there is always high response rate.

\section{Pilot Results}

The researcher did reliability and validity tests to confirm whether the instruments used were understood and tested what they were intended to test. The pilot test was carried out to detect any weaknesses in design and instrumentation and to provide proxy data for selection of a sample (Mugenda\&Mugenda, 2003). As stated by (Kombo\& Tromp, 2006) a pilot study was meaningful when a questionnaire was given to just a few people with an intention of pre-testing the questions. Pilot test was an activity that assisted the researcher in determining if there were flaws, limitations, or other weaknesses within the interview designed and allowed to make necessary revisions prior to the implementation (Kamungeet al., 2014). The rule of thumb was that $1 \%$ of the sample should constitute the pilot test (Mugenda\&Mugenda, 2003). The proposed pilot test was within the recommendation. 


\section{Pilot Test Reliability Results}

\begin{tabular}{lccc}
\hline Statement & Number of Items & Co-efficient Alpha & Comment \\
\hline Loans & 6 & 0.793 & Accepted \\
Trade Credit & 6 & 0.771 & Accepted \\
Equity financing & 6 & 0.785 & Accepted \\
Informal Finances & 6 & 0.817 & Accepted \\
\hline
\end{tabular}

Cronbach's alpha purposely determined the reliability of the questionnaire. In their study, (Nderituet al., 2015) showed that Cronbach alpha values ranges between 0 and 1.0; while 1.0 indicated perfect reliability, the value 0.70 was deemed to be the lower level of acceptability. Cronbach's alpha for each of the predictor variable was well above the lower limit of acceptability of 0.70 . The findings indicated that loans had a coefficient of .793 , trade credit had .771 , equity finance had .785 and informal Finances had 0.817. These results showed that almost all the sections and questions obtained a Cronbach's alpha of more than 0.7. The study also assessed the responses per question to determine if there were any technical snags with the questions. Thus, the results indicated that the questionnaire used in this study was reliable for conducting the major research.

\section{Normality Test Results}

In this section, normality tests were performed for the dependent and independent variables before subjecting the study variable sets to other statistical tests. Measures of Skewness and Kurtosis, were mostly used as the first measure of Skewness based on mean and mode or on mean and median. Other measures of Skewness, based on quartiles or on the methods of moments, were also used sometimes. Kurtosis was the measure of flat-topped-ness of a curve. A bell shaped curve or the normal curve was mesokurtic because it was Kurtis in the center; but if the curve was relatively more peaked than the normal curve, it was called Leptokurtic whereas a curve was more flat than the normal curve, it was called Platykurtic.

The results on Kurtosis were the humped-ness of the curve and points to the nature of distribution of items in the middle of a series (Mugenda\&Mugenda, 2003). Skewness and Kurtosis tests were used to measure symmetric distribution and peak-ness of distribution respectively. The values of asymmetry and kurtosis between -2 and +2 were considered acceptable to prove distribution normality as indicated by (Kombo\& Tromp, 2006). The Skewness and kurtosis measures should be as close to zero as possible. However, in reality, data were often skewed or kurtosis. A small departure from zero was therefore not a problem as long as the measures were not too large compared to standard errors. In this study, the Skewness and kurtosis were within the accepted ranges. It was therefore assumed that the data were approximately normally distributed in terms of Skewness and kurtosis from the measure of the independent variable as seen in the table below.

\section{Skewness and Kurtosis}

\begin{tabular}{lccccrr}
\hline & $\mathrm{N}$ & Std. Deviation & \multicolumn{2}{c}{ Skewness } & \multicolumn{2}{c}{ Kurtosis } \\
& \multicolumn{1}{c}{ Statistic } & Statistic & Statistic & Std. Error & Statistic & Std. Error \\
\hline $\begin{array}{l}\text { Financial } \\
\text { performance }\end{array}$ & \multirow{2}{*}{300} & .50262 & -.442 & .223 & -.218 & .112 \\
\hline
\end{tabular}

Valid N

(listwise)

The dependent variable for this study was financial performance. Kolmogorov-Smirnov was used to check if the data set was from a particular distribution and if it confirmed the normality. This is a non-parametric test and is therefore applicable for continuous distributions. According to (Mugenda\&Mugenda, 2003) Kolmogorov-Smirnov (K-S) onesample test was a non-parametric goodness of fit test that compares the cumulative distribution function for variables within a specific distribution and this was finally computed. The Kolmogorov-Smirnor (K-S) one sample test was run and presentation of the results was as in Table 4.4. 
One-Sample Kolmogorov-Smirnov Test

\begin{tabular}{llr}
\hline & & Financial performance of SMEs \\
N & & 300 \\
Normal Parameters(a,b) & Std. Deviation & 20.61 \\
Most Extreme Differences & .488 \\
& Absolute & .398 \\
& Positive & .284 \\
& Negative & -.398 \\
Kolmogorov-Smirnov Z & & 11.745 \\
Asymp. Sig. (2-tailed) & & .612 \\
\hline
\end{tabular}

a Test distribution is Normal.

b Calculated from data.

The null hypothesis showed that the sample was drawn from a normal data. The data followed the normal distribution since the Asymp. Sig. (p-value) was 0.612 which was greater than the one set at $p>0.05$. The results indicate the Kolmogorov-Smirnov Z was 11.745 and hence the null hypotheses were rejected.

\section{Background Statistics}

This section summarized the characteristics of the general data statistics. The results of the tests on the differences in means of all predictor variables were considered on dependent variable and the moderating effect of size of SME on the effect of sources of finance on financial performance of SMEs in Kenya.

Their respective mean, range, standard deviation, kurtosis, minimum and maximum values were considered. Descriptive statistics were also used to describe the basic features of the data in the study and the key trends of the variables over the period. They provided simple summaries of the measures. Descriptive statistics such as graphs, key categorizations and percentages were used to analyze the data.

\section{Location of Respondent}

The researcher sought to determine the number of respondents and their location for an easier survey and a more knowledgeable approach on the credit environment and the scale management of the research. From the Table 4.5 below, it was evident that most Respondents occur in the main cities and town. The study showed that high numbers of the SMEs were found in Kitui, Nairobi and Mombasa. The results were as presented in Table 4.6.

\section{Respondent's location}

\begin{tabular}{ccc}
\hline County & requency & Percentage \\
\hline Nairobi County & 53 & 17.7 \\
Mombasa County & 51 & 17.0 \\
Machakos County & 48 & 16.0 \\
Makueni County & 47 & 15.7 \\
Kajiado County & 43 & 14.3 \\
Kitui County & 58 & 19.3 \\
\hline
\end{tabular}

A total of three hundred respondents answered the research questionnaires.

\section{Registration Status}

The researcher sought to establish the registration status of the SMEs. It was established that (80\%) of the SMEs were registered hence were in a position to obtain financial assistance from any financial institution. The information was obtained from the data presented in Table 4.6. 
Registration status of SMEs

\begin{tabular}{lcc}
\hline Status & Frequency & Percentage \\
\hline Registered & 240 & 80 \\
Not Registered & 60 & 20 \\
\hline Total & $\mathbf{3 0 0}$ & $\mathbf{1 0 0}$ \\
\hline
\end{tabular}

The registered SMEs were sufficient for giving meaningful data analysis. These findings show that many of the businesses were registered. These findings agreed with Njeru (2013) that many businesses are registered due to the requirement of the law.

\section{Form of ownership}

The researcher sought to establish the different forms of ownership. This ownership included sole proprietorship, partnership and company among others. The data presented in Table 4.7.

\section{Form of ownership of SMEs}

\begin{tabular}{lcc}
\hline Form & Frequency & Percentage \\
\hline Sole proprietorship & 180 & 60.0 \\
Partinership & 120 & 40.0 \\
\hline Total & $\mathbf{3 0 0}$ & $\mathbf{1 0 0}$ \\
\hline
\end{tabular}

It was established that sole proprietorship was (60\%) and partnership was $40 \%$. However there was no company or any other form of businesses among the SMEs. These findings agreed with Njagiet al ., (2017) and Njeru (2013) where sole proprietorship have few legal formalities to form and the capital requirement is also low when compared to other forms of business units.

\section{Length of operation}

Establishment of the period of operation for the SMEs was also sought by the study. The data was presented in Table 4.8.

\section{Length of operation of SMEs}

\begin{tabular}{lcc}
\hline Length of operation & Frequency & Percentage \\
\hline Less than 5 & 45 & 15.0 \\
$5-10$ years & 216 & 72.0 \\
Above 10 Years & 39 & 13.0 \\
\hline Total & $\mathbf{3 0 0}$ & $\mathbf{1 0 0}$ \\
\hline
\end{tabular}

It was noticed that (72\%) of SMEs had been in operation for 5-10 years. This number had operated long enough to give reliable information on performance of SMEs. These results agreed with Musamali and Kipkirong (2013) that older firms do not fail at high rate than the younger firms since the older firms have high access to finance due to the high assurance that they give to the lenders on their financial sustainability. More so the older firms are considered to have established good relationship with lenders and are observed to have high probability of accessing funds from the lenders.

\section{Business location}

The researcher sought to establish the location of the businesses to ascertain whether they werewithin the central business district (CBD) or not. The nearness to CBD would imply proximity to information about financial services (Njeru, 2013). Those near the CBD had high chance of being aware of the presence of loans leading to acquiring the same as opposed to those far from the CBD. The responses were presented in Table 4.9. 


\section{Proximity of SMEs from CBD}

\begin{tabular}{lcc}
\hline Length of operation & Frequency & Percentage \\
\hline Near CBD & 168 & 56.0 \\
Far from CBD & 132 & 44.0 \\
\hline Total & $\mathbf{3 0 0}$ & $\mathbf{1 0 0}$ \\
\hline
\end{tabular}

It was however established that most (56\%) of the SMEs were located within the CBD. This implies that high numbers of the businesses were within the CBD hence able to access loans and thus give more reliable information concerning the effect of loans on performance. The findings agreed with Njeru (2013) where the study stated that SMEs near towns or within towns have high chances to get financial information.

\section{Number of employees}

The researcher sought to establish the number of employees for the SMEs and it was found that $95 \%$ of the SMEs under the study had 1- 9 employees. The results were presented in Table 4.1.

Number of employees

\begin{tabular}{lcc}
\hline Number & Frequency & Percentage \\
\hline $1-9$ & 285 & 95.0 \\
$10-49$ & 15 & 5.0 \\
$50-100$ & 0 & 0.0 \\
Over 100 & 0 & 0.0 \\
\hline Total & $\mathbf{3 0 0}$ & $\mathbf{1 0 0}$ \\
\hline
\end{tabular}

It was found that $95 \%$ of the SMEs under the study had 1-9 employees. This means that most businesses were small and thus requiring more financial support. These results agreed with Caroline and Muturi (2015) that many businesses are established as family businesses and may not seek growth plans.

\section{Reliability}

The study conducted a pilot test analysis to ascertain if the research instruments used would bring reliable information. Each firm was to return 6 sample questionnaires each making a total of 36. The SMEs were responsible for their own answers and only one questionnaire was filled by either the CEO or the management, most preferably in the finance, marketing, accounts or the supply environment. The questionnaires were given and follow up calls were administered until questionnaire sheets were given back.

Reliability was the base for the ability of perfect research instruments in giving thorough similar answer within the same circumstances from time to time ((Mugenda\&Mugenda, 2003). Thus if the respondents answer a questionnaire in the same way, then the questionnaire was said to be reliable. Reliability gives the same answers under the same questions in different rates and conditions and this measurement was mostly used to ascertain the reliability of data and results.

\section{Individual Variable Reliability Statistics}

Cronbach's Alpha determined the reliability of the questionnaires used. The Cronbach's Alpha values should range from 0 to 1.0 where 1 indicated perfect reliability and the value 0.7 was said to be the lower level of acceptability (Nderituet al., 2015). The results were presented in table 4.11.

Sorted Reliability Variables for Individual Variables

\begin{tabular}{lcc}
\hline Statement & Co-efficient Alpha & Sub-values \\
\hline Loans & 0.821 & 4 \\
Trade Credit & 0.844 & 5 \\
Equity & 0.788 & 6 \\
Informal Finances & 0.794 & 6 \\
Performance of the business & 0.721 & 5 \\
\hline
\end{tabular}


The Table 4.11 above showed the total reliability segments for individual variables which indicated the values of variables were all accepted as the values obtained were all above 0.7 .

The pilot research had promising reliability sets and thus motivated the next move to conduct a thorough research.

\section{Validity}

Validity was used to test the level and degree that the results obtained from the analysis of data actually represent the phenomenon under study. Validity will help us to determine the accuracy and meaningfulness of inferences, which are based on the research results. Validity shows whether the research instruments measures what is supposed to measure ( Mugenda\&Mugenda ,2003). As explained by Kaiser-Mayor-Oklin Measures of Sampling Adequacy (KMO) and Bartlett's Test of Sphericity was a measure of sampling adequacy that has high recommendation to check the case to variable ratio for the analysis being conducted. In most academic and business studies, KMO and Bartlett's test plays a very key role for accepting the sample adequacy. While the KMO ranges from 0 to 1 , the world-over accepted index was over 0.5. Also, the Bartlett's Test of Sphericity relates to the significance and thereby showed the validity and suitability of the responses collected to the problem being addressed through the study. For Factor Analysis to be recommended suitable, the Bartlett's Test of Sphericity must be less than 0.05 (Nderituet al., 2015).

The study applied the KMO Measures of Sampling Adequacy and Bartlett's Test of Sphericity to test whether the overall relationship among the variables was significant or not as shown in Table 4.12. The Kaiser-Meyer-Olkin Measures of Sampling Adequacy showed the value of test statistic as 0.687 which was more than 0.5 then an acceptable index. While Bartlett's Test of Sphericity showed the value of test statistic as 0.000 which was less than 0.05 acceptable indexes. These result indicated a highly significant relationship among variables.

\section{Overal KMO and Bartlett's Test}

\begin{tabular}{llr}
\hline Kaiser-Meyer-Olkin Measure of Sampling Adequacy. & .687 \\
Bartlett's Test of Sphericity & Approx. Chi-Square & 22.599 \\
& Df & 3 \\
& Sig. & .000 \\
\hline
\end{tabular}

\section{Effect of equity financing on performance of SMEs}

The results on effect of equity financing on financial performance of SMEs in Kenya were presented in the table 4.25 below.

\section{Use of personal savings}

\begin{tabular}{lcc}
\hline Response & Frequency & Percentage \\
\hline Yes & 276 & 92.0 \\
No & 24 & 8.0 \\
Total & $\mathbf{3 0 0}$ & $\mathbf{1 0 0}$ \\
\hline
\end{tabular}

It was established that high rate which was $(92 \%)$ of the SMEs had used personal savings to finance their businesses. These findings agreed with Njeru (2013) where it was found that most businesses are financed using personal savings. The amount of equity financing used by SMEs ranged between Kshs 35,000 to Kshs 900,000.

The study also sought the presence of business partners and the results were presented in the table 4.26.

Results on presence of business partners

\begin{tabular}{lcc} 
Response & Frequency & Percentage \\
\hline Yes & 84 & 28.0 \\
No & 216 & 72.0 \\
Total & $\mathbf{3 0 0}$ & $\mathbf{1 0 0}$ \\
\hline
\end{tabular}


It was found that $(72 \%)$ of the SMEs had no business partners. These findings agree with Njagiet al., (2017) that most businesses do not allow business partners so that they can ensure that they maintain full control of the business. The researcher further sought establishing the linear regression model to show the contributions of equity financing on performance of SMEs. The results were that $\mathrm{R}^{2}=0.682$ and $\mathrm{R}=0.651$ where this indicated that there was a linear association between equity financing and the performance of SMEs. The independent variable can only explain $68.2 \%$ of variability of dependent variable

\begin{tabular}{lllll}
\multicolumn{4}{l}{ Model Summary for equity financing } \\
\hline Model & $\mathrm{R}$ & $\mathrm{R}$ Square & Adjusted R & Std. Error of the \\
& & & Square & Estimate \\
1 & $.651 \mathrm{a}$ & .682 & .623 & .352 \\
\hline
\end{tabular}

Predictors: (Constant), cost of Equity financing X3

Table 4.29 shows the results of ANOVA test which reveals that the variable Equity financing positively was associated with the performance of SMEs in Kenya, $F(1,299)=29.365, p<.05, R^{2}=.682$.

\section{ANOVA (F-Test) Analysis for equity financing}

\begin{tabular}{llccccc}
\hline Model & & $\begin{array}{c}\text { Sum of } \\
\text { Squares }\end{array}$ & Df & Mean Square & F & Sig. \\
& Regression & 23.564 & 1 & 52.121 & 29.365 & $.000(\mathrm{a})$ \\
& Residual & 10.235 & 299 & .428 & & \\
& & & & & \\
& Total & 33.799 & 300 & & & \\
& & & & \\
a Predictors: (Constant), equity financing \\
b Dependent Variable: Performance of SMEs
\end{tabular}

From table 4.29, the linear regression model for performance of SMEs,

$\mathrm{Y}=\beta 0+\beta_{4} \mathrm{x}_{4}+\varepsilon$

Where;

$\mathrm{Y}=$ Performance of SMEs in Kenya

$\beta_{0}=$ Constant (Y- Intercept)

$\varepsilon=$ Standard Error term

$\mathrm{X}_{4=}$ equity financing

Performance of SMEs in Kenya $\mathrm{Y}=1.442+0.924$ equity financing. From regression results, a 0.924 increase in equity financing resulted into one unit increase in performance.

\section{Coefficients for equity financing}

\begin{tabular}{llccccc}
\hline & & \multicolumn{2}{c}{$\begin{array}{c}\text { Unstandardized } \\
\text { Coefficients }\end{array}$} & $\begin{array}{c}\text { Standardized } \\
\text { Coefficients }\end{array}$ & $\mathrm{T}$ & Sig. \\
$\begin{array}{l}\text { Model } \\
1\end{array}$ & & B & Std. Error & Beta & B & Std. Error \\
& (Constant) & 1.442 & .241 & & .521 & .001 \\
& Equity financing & 0.921 & 1.331 & .421 & 9.332 & .000 \\
\hline
\end{tabular}

a Independent Variable: equity financing

The findings showed a statistical significant association between Equity financing and financial performance of SMEs. These findings were in line with those of Kenduiwo (2014), Njagiet al., (2017) and Waithaka and Njeru (2015).

\section{Summary, Conclusions and Recommendations}

\section{Summary of the findings}


The findings suggested that the Equity financing had a statistical significant relationship with the performance of the SMEs. The findings were summarized as per the objectives.

\section{Equity financing and performance of SMEs}

Equity finances significantly predicted the performance of SMEs in Kenya. The correlation results indicated that, there was also a significant positive correlation between equity funds and size of the SMEs.

\section{Conclusions}

The multiple regression results indicated that the equity finances positively predicted the performance of SMES in Kenya. The results of the linear regression resolved that there was a strong linear relationship between finance source and the performance of SMEs in Kenya. When the hypotheses were tested in the regression model, the independent variables were found to have a significant association with the performance of SMEs in Kenya.

All other SMEs in Kenya should apply the four variables and sub variables used in the study so that faster growth for each SMEs in Kenya could be realized. The study findings would contribute knowledge to assist in the business growth. Not much had been done on the four variables on sources of finance. Most of the studies on SMEs especially had been focusing more on working capital and growth. Thus the findings of this study would contribute a lot in filling knowledge gaps by focusing on the effect of sources of finance on performance of SMEs.

\section{Recommendations}

\section{Equity finances and financial performance of SMEs in Kenya}

Most of the SMEs had used personal savings to finance their businesses. This method of saving is expected to take long before one gets enough money to finance his/her business. This study therefore recommends that SMEs should be encouraged to take loans or trade credit to finance their businesses instead of waiting to raise money. This would help them to begin their businesses earlier.

\section{References}

Abbasi , A. \& Malik, Q. (2015) Firm size moderating financial performance in growing firms an empirical evidence from Pakistan. International journal of economics and financial issues vol 5 issue 2.

Abdulaziz, M.A \& Andrew, C.W. (2013 ). Small and medium sized enterprises financing.A review of literature.International journal of business management vol 8 issue No14

Abdur, R. \&Kashif, K. (2016). A review of impact of trade credit on firm's profitability: Study of non-financial firms in Pakistan.Journal of poverty, investment and Development Vol 25.

Abiodun ,E. \&Entebang, H. (2015). SME firm performance financial innovation and Challenges.University of Malaysia, Sarawak Malaysia.

Aloy, N.J. \&Velnampy, T. (2014). Firm size and profitability: a study of listed manufacturingFirms in Sri Lanka.International journal of business and management Vol 9 issue 4.ADBI working paper series No 581, 2016.

ADB \& OECD (2014). Study on enhancing financial accessibility for SMEs. issue 5 pp 169- 179.

Akinyi, S. I. (2014).The effect of bank financing on the financial performance of SMEs in Nairobi County Kenya. University of Nairobi unpublished MBA project.

Ambrose, J. (2012). Venture capital: The all-important MSMEs financing strategy under neglect in Kenya. International journal of business and social science vol 3 No 21.

Amidu M. (2007). Determinants of Capital Structure of Banks in Ghana: An Empirical Approach, Baltic Journal of Management, 2(1), 67-69.

Antwi,S,K. \& Hamza, K. (2015).Qualitative and Quantitative research paradigms in business Research: A philosophical reflection. European journal of business and management vol 7 issue 3 .

Beck, T., \& Cull, R. (2014). Small- and medium-sized enterprise finance in Africa.Africa Growth Initiative.

Brooks, C. (2014). Introductory Econometrics for Finance. 3rd edn. New York: Cambridge University Press.

Bwana, K. M., \& Mwakujonga, J. (2013). Issues in SACCOS Development in Kenya and Tanzania: The Historical and Development Perspectives.Developing Country Studies Vol.3, No.5.

Chimaleni,J., Muganda, M. \& Musiega, D. (2015). Relationship between sources of business financing and financial performance of SMEs in Lurambi sub- county. International journal of business and management invention vol 4 issue $7 \mathrm{pp} 35-45$.

Kenya Commission of revenue allocation report 2015. 
Kenya Economic survey report 2016.

Kenya Economic survey report 2017.

Emad, H. , Suhail , A. , \& Jabbar, A. (2014). The influence of finance on performance of small and medium enterprises in Iraq. International journal of engineering and innovative technology volume 4 issue 3.

European Commision. (2016). Small and Medium-Sized Enterprises' Access To Finance. European Semester Thematic Fiche.

FSD Kenya, \& Growth Cap. (2016). Financing SME growth in Kenya. Nairobi: FSD Kenya.

Gilchris, 2013). Impact of monetary policy interest rates on performance of small and Medium sized enterprises. IOSR journals.

Githire, C. \& Mutiri, W. (2015). Effects of capital structure on financial performance of firms in kenya; Evidence from firms listed at the Nairobi securities exchange. International journal of economics, commerce and management vol 3 issue 4.

Grover, A., \& Suominen, K. (2014). Trade-up. State of SME Finance in the United States, 38.

Gujarati, D. (2004). Basic econometrics. Boston: McGraw Hill.

Hari (2016). A study into Small and medium enterprises across Europe by Microsoft with Hult international business school.

Ihuah,P.W. \& Eaton, D. (2013). Journal of US- China public administration vol 10 issue 10 pp 933-944.

ILO(2015).The importance of informal finance in promoting decent work among informal operators: A comparative study of Uganda and India. Working paper No 66.

Jackson, E. (2013) Choosing a methodology: Philosophical underpinning, Practitioner Research in Higher Education Journal vol 7 issue 1.

Janet, M. \& Ngugi, K. (2014). Influence of Entrepreneurial Marketing on the growth of SMEs in Kiambu Town - CBD, Kenya. European journal of Business Management, 1 (11), 361 -377.

Jensen, M.C.,\& Meckling, W.H.(1976). Theory of the firm: Managerial behavior, agency costs and ownership structure. Journal of financial economics.

Kamau, G.K. (2011). Factors influencing small and medium enterprises access to finance a case study of Westland division Kenya. Mount Kenya university respitory.

Kamunge ,S.M , Njeru,A. \& Tirimba ,O.I.(2014). Factors affecting the performance of small and micro enterprises in limuru town market of kiambu county kenya. International journal of scientific and research publications vol 4 issue 12.

Kangala, F. (2016). Factors that affect financial performance of small and medium enterprises in Kenya. unpublished MBA project USIU-A

Kapkiyai, C., \& Mugo, R. (2015). Effect of trade credit on financial performance of small scale enterprises: evidence of Eldoret town, Kenya. International Journal of Economics, Commerce and Management Vol III.Issue 9.

Katua, N. T. (2014). The Role of SMEs in Employment Creation and Economic Growth in selected Countries. Unpublished MBA project university of Nairobi.

Kenduiwo, M. (2014). The relationship between alternative sources of finance and financial performance of small and medium enterprises in Nairobi County. International Journal of Education and Research Vol. 2 No. 12.

Kenya National Bureau of Statistics SMEs report 2016.

Kepha, O. \& Muturi, W. (2013). The role of micro financial institutions on the growth of SMEs in Kenya. A case study of microfinancial institutions in Kisii town. IOSR Journal of humanities and social science Vol 16 issue $1 \mathrm{pp}$ 83-93.

KNBSCounty statistical abstract 2015.

Kombo, D.K. \& Tromp, D.L.(2006). Proposal and thesis writing: An introduction. Paulines publication Africa.

Kuria, F.B. (2013). The effect of capital structure on the financial performance of commercial banks in kenya. Unpublished MBA project university of Nairobi.

Martin, A. \& Filip, L.(2016). The impact of financial performance on SMEs utilization of trade credit.

Memba (2011) .Impact of venture capital finance on performance of small and medium enterprises in Kenya. Unpublished PHD Thesis Jomo Kenyatta University.

Mesut, D.(2013). Does firm size affect the firm profitability: Evidence from Turkey. Research journal of finance and accounting vol 4 issue 4

Modigliani, F. \& Miller, M. (1958). The Cost of Capital, Corporation Finance and The Theory of Investment, American Economic Review, 48, 261-97.

Modigliani, F. \& Brumberg, R. H. (1954). Utility analysis and the consumption functions an interpretation of cross section data. Rutgers University Press pp 388-436. 
Mohammed ,I. \& Ali, I. (2015). The effect of SMEs cost of capital on their financial performance in Nigeria. Journal of finance and accounting volume 3 issue 1

Mugenda, O. M., Mugenda, A. G. (2003). Research Methods: Quantitative and Qualitative Approaches, Acts Press, Nairobi-Kenya.

Muinde, G. M. (2012). Relationship between financial structure and growth of saving and credit cooperative societies' wealth in Machakos County. Unpublished MBA project universityof Nairobi.

Muigai, R.G.\& Muriithi, J.G.(2017). The moderating effect of firm size on the relationship between capital structure and financial distress on non- financial companies listed in kenya. Journal of finance and accounting vol 5 issue 4 pp 151-158.

Mukoma , F.K. \& Masini , D.O.(2015). Effects of microfinance institutions products on financial performance of small and medium enterprises in Machakos town Kenya. Unpublished MBA project University of Nairobi.

Muriithi ,S. (2014). The effect of financing sources on the financial performance of the top 100 mid sized companies in kenya. Unpublished MBA project university of Nairobi.

Murigi,M. (2014). The effect of financial access on the financial performance of small and micro enterprises in Mukuru slums, Kenya. unpublished MBA project University of Nairobi.

Musamali,M.M. \& Kipkirong, D.T. (2013) Does firm profile influence financial access among small and medium enterprises in Kenya. Asian economic and financial review

Musara, M. \& Olawale ,F. (2012). Access to finance in the SME sector. A South Africa perspective. Asian journal of business management vol 4 issue 1.

Muturi, W.M. (2012). Determinants of participation in rotating savings and credit associations in urban informal settlements: Evidence from mathare slums Nairobi. Unpublished Phd thesisJomo Kenyatta University.

Mwangangi (2013) . Relationship between trade credit and value of firms listed at the Nairobi securities exchange. Unpublished MBA project University of Nairobi .

Mwangi, M. (2015).The effect of capital structure on the financial performance of small and medium sized enterprises in Thika sub- county Kenya. International journal of humanities and social science vol 5. No 1.

Mwega, F. M. (2014). Financial regulation in Kenya: Balancing inclusive growth with financial stability. Overseas Development Institute - Working Papers 407.

Namusonge, G. S. (2010). Business Statistics: Concepts and Applications. Beau Bassin, Mauritius: VDM Publishing House Ltd.

Nderitu,P. G. \& Githinji C, K. (2015). Debt financing and financial performance of small and medium size enterprises; evidence in kenya. Journal of Economics, Finance\& Accounting JEFA (2015), vol.2 (3).

Nigusie, D. (2015). Determinants of savings and credit cooperatives societies outreach in Addis Ababa. Addis Ababa University repository.

Njagi,I.K., Kimani, E.M. \& Kariuki, S. (2017). Equity financing and financial performance of SMEs in Embu town kenya. International academic journal of economics and finance Volume 2 Issue $3 \mathrm{pp}$ 74-91.

Njeru, A. W. (2013). Determinants of Choice of Source of Entrepreneurial Finance for Small and Medium Size Enterprises. Survey of Thika, District Kenya. Unpblished Phd thesis Jomo Kenyatta University.

OECD. (2014). Small businesses, job creation and growth: facts, obstacles and best practices Retrieved 04 16, 2017, from OECD: www.oecd.org/cfe/smes/2090740.pdf.

Olawale ,L. (2017). The effect of firm size on performance of firms in Nigeria.The IEBinternational journal of finance vol15 issue 2.

Omondi,J.W. (2014).The effects of receivable management practices on receivable impairement in sugar companies in kenya. Unpublished MBA project university of Nairobi.

Onyiego, G.O. , Namusonge ,G.S. \& Waiganjo, E.(2017). The effect of access to finance on financia performance of SMEs in Mombasa County Kenya. The strategic journal of business and change management vol 4 issue $3 \mathrm{pp}$ 335 - 346.

Owusu, I. \&Allotey, N.A. (2014) . The impact of money lending institutions on SMEs in Ghana Global journal of management and business research in finance vol 14 issue 5 .

Quaye, I. \& Sarbah, A. (2014) Alternative sources of finance for SMEs in Ghana. International journal of advancements in research and technology, vol 3 issue 7.

Raude,J.M., Wesonga,W. \&Wawire, P.(2015). Equity financing strategy and the performance of small and medium enterprises in kenya. International journal of business and management. vol 10 issue 4.

Rosana \& Muturi,W. (2014). Factors influencing choice of source of business finance by small and medium enterprises; A survey of Thika municipality. International journal of financial economics vol 2 issue 4.

Shan, B.A. (2013). Credit constraits on small and medium sized enterprises evidence from China. Georgetown ,Washington D.C. 
Stangor, C. (2011). Research methods for the behavioral sciences; 4th ed. Australia; Belmont, CA: Wadsworth: Cengage Learning.

Phyllis, P. (2016). The role of finance in Kenyan manufacturing. scoping paper

Uche, V. (2015). Accessibility of credit facility from financial institutions by small and medium scale enterprises: Evidence from Nigeria. University of Nigeria virtual library.

Vicente, C. (2012). Determinants of survival of newly created small and medium enterprises in Brazilian manufacturing: An econometric study. Esifo working paper series No 3735.

Wahome, M. (2015). The factors that influence capital structure decisions of quoted insurance companies in Kenya. International journal of scientific and research publications vol 5 issue 8 .

Waithaka, J. M., \& Njeru, A. (2015). Effects of Informal Finance on the Performance of Small and Medium Enterprises in Kiambu County. International Journal of Scientific and Research Publications, Volume 5, Issue 11.

Wambui ,M.D.(2015). The effect of micro finance services on the growth of small and medium enterprises in Kajiado county. Unpublished MBA project university of Nairobi. 